P.S.-Mr. Bristow tells me that he and Professor Ramsay found Coal-measure sandstones with glacial striæe in the Boulder-clay near Cardiff, and that having seen the drift on Exeter Hill near Tiverton, he remarked to Mr. Ussher, who was engaged in mapping the district, that striæ should be looked for, as polished gravel such as that was very suggestive of glacial action.

H. B. W.

\title{
MR. HOPKINSON'S NEW SPECIES OF GRAPTOLITES FROM THE SOUTH OF SCOTLAND.
}

Srr, - While gratefully acknowledging the value of Mr. Hopkinson's researches among the graptolites of the south of Scotland, I beg to enter my protest against part of his paper in the November number of the Magazine.

At p. 501, Vol. IX., it is stated that "The Lanarkshire graptolitic shale is considered by Prof. Geikie to form 'an upper part of the Moffat group,' but while decisive stratigraphical evidence is wanting, from the evidence afforded by the fossils it seems more probable that but one band of graptolitic shale runs through the Llandeilo rocks of the south of Scotland, there being in this band several distinet zones, each marked by a different assemblage of fossils, but with many species in common."

During the progress of the Geological Survey in the Leadhills district, "decisive stratigraphical evidence" was obtained that the Leadhills graptolitic shale group occupies a higher horizon than the Moffat group. This is indicated in the Explanation of Sheet 15 of the Geological Survey Map.

From the localities given in Mr. Hopkinson's paper, it appears that of the ten new species of graptolites described by him, two are peculiar to the Moffat group, six peculiar to the Leadhills group, and two common to both. There is not, here at least, much "evidence afforded by the fossils" of the identity of the two groups. What I object to on Mr. Hopkinson's part is his describing the whole ten new species as "graptolites from the Moffat group," thereby mixing up fossils which it is of the utmost importance to keep separate. I am confident that neither Professor Geikie, nor either of my colleagues, Messrs. Horne and Skae, who have since the survey of the Leadhills group carried on the work into the Moffat group, would for a moment entertain the idea of their identity.

Even where there really is an absence of stratigraphical evidence, it seems to me that the best course is not to slump together all the fossils collected within a certain area and call them a "group," but to distinguish the fossiliferous rocks bed by bed, if need be.

Of the localities in question a glance at Sheet 15 of the Geological Survey Map will show the following to be in the Leadhills group, viz., Wanlock Water, Kirk Gill, Lowen Dod, and Laggen Gill. Lochan Burn, Frenchland Burn, Garple Linn, and Moniave (?) probably lie within the limits of the Moffat group. I trust, therefore, that pending the issue of the Geological Survey Menuoir on the holew 
Southerm Silurian region, Mr. Hopkinson will accept the undernoted grouping of the new species:-

\author{
Moffat Grote,- \\ Corynoides gracilis. \\ Graptolithus acutus. \\ LeaDhiLLS GrodP,- \\ Dendrograptus ramulus. \\ Diplograptus Etheridgii. \\ pinguis.
}

Geological Surfey,

ALEXANDrIa, 11 Nov., 1872.

\author{
Diplograptus fimbriatus. \\ Dieranograptiscksii. \\ Dicranograptus rectus. \\ Common to Mofrat aNd LeadHLlls \\ GrouP,- \\ Graptolithus attenuatus. \\ Diplograptus penna.
}

R. L. JAK.

\section{THE DIVINING ROD IN ESSEX.}

SIR,-Mr. H. B. Woodward's surprise as to the existence of a belief in the powers of the Divining Rod will, I think, give way as he finds it is much more firmly believed in by west-country people than is commonly imagined. A few days ago I was travelling in company with a gentleman to whom I bad been introduced, who is a civil engineer and architect. He was telling me of some borings he had to conduct in Essex, in the London-clay, for water. I immediately referred him to Mr. W. Whitaker's recently published memoir on the London Basin, in which is given such a copious list of well and other borings, thinking these might help him. I was replied to with a smile of self-satisfaction, and presently informed that when he wished to find water, he always used a forked hazel wand, which plainly and distinctly "turned in his hand" in the direction where water lay, and that he had never known this plan to fail! My purpose in writing is to recommend the practice to the Geological Survey, so that a corps of hazel-wand explorers might be formed and drilled! It would be a novelty to have a "Professor of the Divining Rod" at Jermyn Street!

IPEWICH.

J. E. TAylor.

\section{CORALLINE CRAG FOSSILS.}

SIr,-As Dr, Allman has not confirmed the statement made in the GEOL. MAa. (antè p. 337) respecting the presence of Purpura lapillus in the Coralline Crag, I presume the name of that species cannot be introduced into my Catalogue.

Hydractinia is a fossil not very rare in the Coralline. Crag, and I have also found it in the Red Crag, but in this latter formation it is possibly a derivative from the older bed. The shell this Hydroid has generally selected for investiture is Trophon consociale (Crag Moll., vol. i, p. 49, tab. vi.f. 11): a specimen now in my possession has nearly half the shell exposed. This fossil bas been long known, and the name of it was inserted in my " Catal. of Zoophytes from the Crag "(Ann. and Mag. Nat. Hist. vol. xiii. p. 21,1844 ), as Alcyonidium cercumvestiens. The generic name Alcyonidium, Lamournux, was adopted by Dr. Geo. Johnston in his work on the British Zoophytes, where, at p. 304, he describes Alcyonium echinatum of Montague and Fleming, and of which a very indifferent and incorrect figure is given. He there speaks of the papillæ as "arranged in rows," but those upon the fossil not having that regularity, and apparently larger and comparatively fewer in number, as well as having the layers in some parts (from successive generations) of nearly half an inch in thickness, I thought it might be specifically distinct. I have, however, since then obtained a recent specimen covering a dead shell of Natica catena, on which the papillæ are not in rows, but irregular, like those upon the Crag fossil. Its correct specific determination must be left for future observers.

Searles V. Wood. 